\title{
Foreign Direct Investment and Economic Performance Nexus in ECOWAS: Does Human Capital Matters?
}

\author{
Hilary Temofeh KANWANYE, Ph.D ${ }^{1}$ Kehinde Hussain OGUNBADEJO² \\ Nosakhare Liberty ARODOYE, (Ph.D) ${ }^{1}$ \\ 1.Department of Economics, University of Benin, Benin City, Nigeria \\ 2.Nigerian Institute of Oceanography and Marine Research, Victoria Island, Lagos
}

\begin{abstract}
Human capital is an important channel through which foreign investment impact on economic performance and this has either been neglected or not given adequate attention by researchers. This paper therefore examined the nexus between foreign direct investment (FDI) and economic performance of Economic Community of West African States (ECOWAS) considering the imperative of human capital channel. A panel of 13 ECOWAS countries from 1980 to 2018 was utilised in a panel cointegration and autoregressive distributed lag estimation. The results indicated that FDI had a positive effect on economic performance of ECOWAS sub-region in the short run, and the effect became significant in the long run. Findings also revealed that human capital hindered the economic performance effect of FDI in ECOWAS, in the short rum and long run through life expectancy, but with a very weak positive impact through education in both time horizons. The paper recommended, amongst others, that ECOWAS as a body and her member nations should establish and entrench policies that would encourage FDI inflow and promote human capital in the sub-region
\end{abstract}

Keywords: foreign direct investment, human capital, economic performance, ECOWAS

DOI: $10.7176 /$ RJFA/12-8-07

Publication date: April $30^{\text {th }} 2021$

JEL Classification: F21, I15, I25, O47

\section{Introduction}

Developing nations of the globe, including member countries of the Economic Community of West African States (ECOWAS), have made efforts to put in place market-oriented policies and mechanism to encourage inflow of foreign direct investment (FDI) into their countries and the region as a whole, to promote growth and development. The ECOWAS trade liberalization policies, which involve having a standard tariff structure among member nations to enable free flow of trade and investment in the region, is one, amongst other measures, to enhance the region's economic prosperity. Despite this measure, the region is characterized by a high poverty rate, low human development index, abysmal savings rate, dwindling welfare of the region, and macroeconomic instability (Ogunbadejo\&Kanwanye, 2020; Ozekhome, 2017).

Available data from the World Development Indicators (WDI) in 2019 reveals that FDI inflows into the ECOWAS countries and the region have been rising in absolute terms over time. Although, the FDI share in the gross domestic product (GDP) of the ECOWAS countries, on average, from 1990 was 1.07\%, in 2000 was $1.57 \%$ in 2010, 2.9\% while in 2018 it increased to 4.51\% (WDI, 2019; Ozekhome, 2017). The GDP of ECOWAS countries have increased over the decades; however, the average real GDP growth rate in the region is still below 5 percent since 2000 (WDI, 2019). More so, the average GDP per capita growth rate has been declining over the past decades. In the 1990s, 2000s and from 2010 to 2018, the average values of GDP per capita growth rate recorded were 4.8, 3.3 and 3.1 percent, respectively (WDI, 2019), reflecting a region's dismal economic performance. A correlation, however, exists between FDI and the economic growth of ECOWAS (Ogundipe, Oye, Ogundipe\&Osabohien, 2020; Fofana, Xia \&Traore, 2018; Ozekhome, 2016).

Moreover, human capital in the ECOWAS sub-region has been improving (WDI, 2019), and several studies (Ogunbadejo\&Kanwanye, 2020; Fadila\&Olure-Bank, 2019; Lawanson, 2015) found significant positive economic growth effect of human capital in the sub-region. However, available studies did not give adequate attention to human capital as a channel by which FDI impacts the economic performance of ECOWAS. The preceding gives rise to these pertinent questions: i. how does the inflow of FDI influence the economic performance of the ECOWAS sub-region? ii. is human capital a channel by which FDI impacts the ECOWAS sub-region's economic performance?

This paper will therefore examine the effect of FDI on the economic performance of the ECOWAS subregion, and it will also ascertain whether human capital development enhances the growth effect of FDI in the ECOWAS sub-region.

This paper is structured into six sections, and following this introductory section are some stylized facts discussed in the second section. A literature review is presented in the third section, while methodology and results are provided in the fourth and fifth sections, respectively. The sixth section concludes the paper. 


\section{Stylized facts}

Available data suggest that economic performance, FDI inflow and human capital in the ECOWAS sub-region have increased over time. For instance, the annual average growth rate of the real GDP of ECOWAS was 2.9 percent in 1980 (Figure 1) and has recorded marginal increases to 3.1, 3.4, 3.8 and 3.5 percent in 1990, 2000, 2010 and 2018, respectively. It indicates that the annual growth rate of the sub-region's economic performance rose by 3.23 percent between 1980 and 2018 .

\section{Fig 1: ECOWAS Annual Average Real GDP Growth}

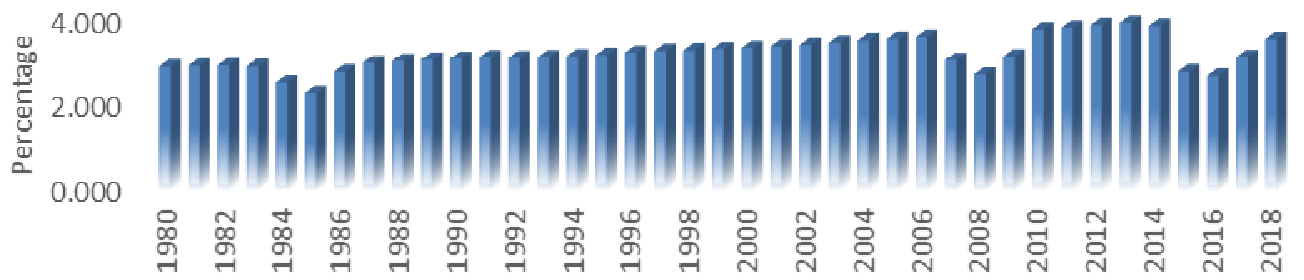

Source: Researchers'sketch using World Development Indicators (2019).

The annual average share of FDI in GDP of ECOWAS also staggered upwards from 1980 to 2018 (Figure 2). Its value dropped from 1.0 percent in 1980 to 0.5 percent in 1983, rose to 2.7 percent in 1986 and dwindled to 0.6 percent in 1988 . It increased significantly to 8.5 percent in 2011 , shrank deeply to 3.2 percent by 2015 , and later rose to 3.6 percent in 2018. Therefore, the annual average share of FDI in the sub-region GDP did not exceed 8.5 percent between 1980 and 2018 .

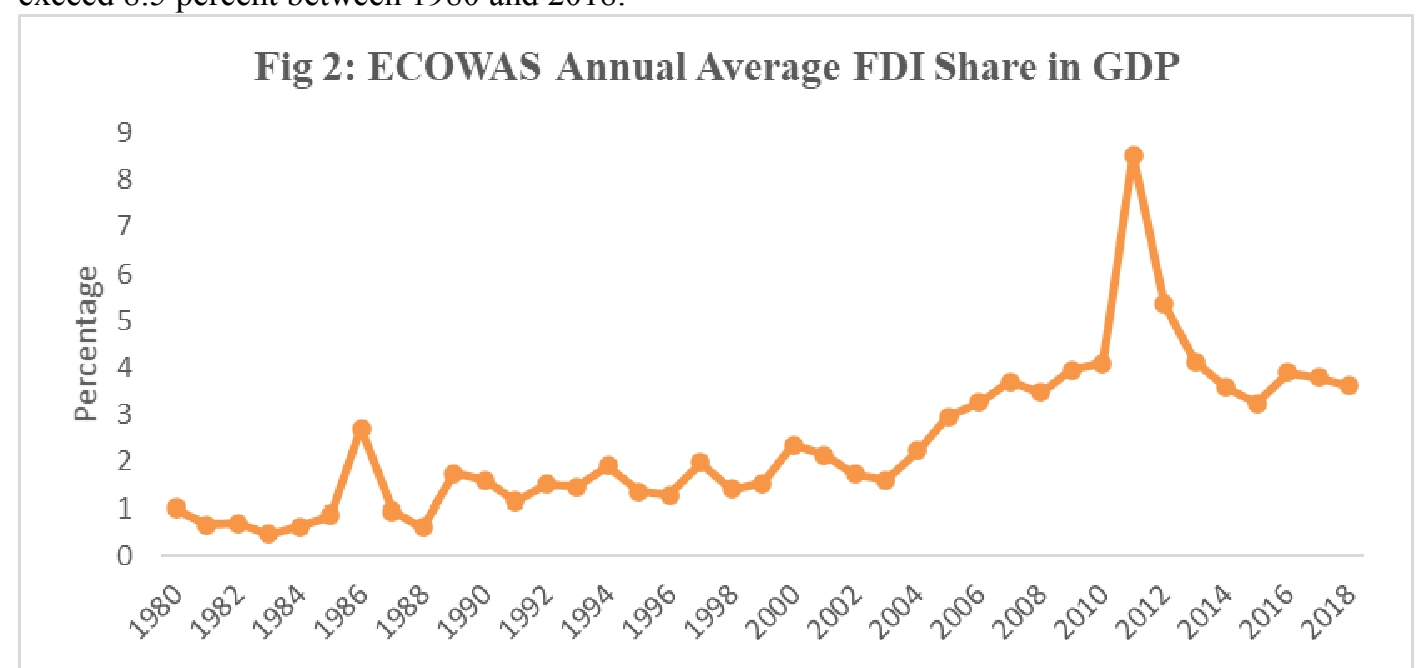

Source: Researchers' sketch using World Development Indicators (2019).

Human capital, in the form of life expectancy at birth and total school enrolment rate, have also been rising in ECOWAS sub-region since 1980. Figure 3 showed that annual average life expectancy at birth in the ECOWAS sub-region increased from 45.8 years in 1980 to 51.0, 56.3, and 58.9 years in 2000, 2010 and 2018 , respectively. 
Fig 3: ECOWAS Annual Average Life Expectancy at Birth

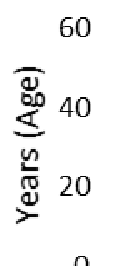

0
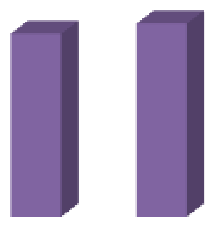

1980

1985

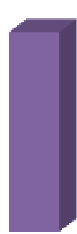

1990

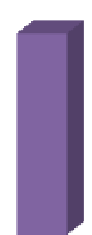

1995

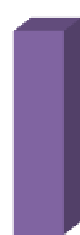

2000

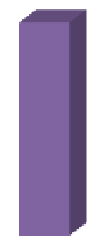

2005

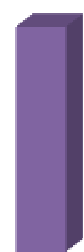

2010

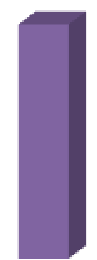

2015

\section{Source: Researchers'sketch using World Development Indicators (2019).}

Moreover, annual average total school enrolment in total population, displayed in Figure 4, indicated that its value rose from 7.8 percent in 1980 to 10.1 percent in 1985 , and dropped to 9.1 percent in 1990 . This value, however, surged significantly from its 1990 figure to 26.1 percent in 2018.

\section{Fig 4: ECOWAS Average School Enrolment percent Population}

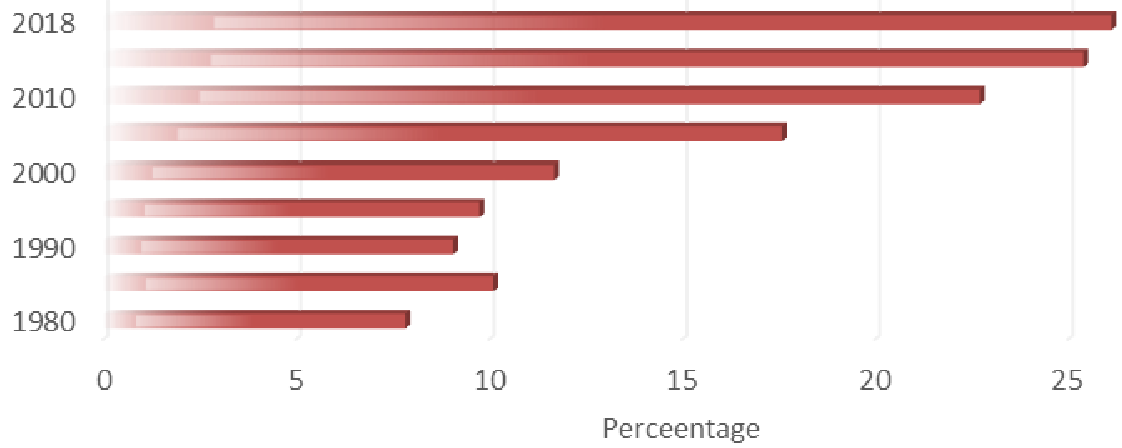

Source: Researchers' sketch using World Development Indicators (2019).

Therefore, an enhanced economic performance of the ECOWAS sub-region is envisaged from theupwardtrajectory of FDI inflow and the human capital indicators.

\section{Literature Review}

\section{Foreign Direct Investmentand Economic Performance}

Yusuf, Shittu, Akanbi, Umar, and Abdulrahman (2020) assessed the role of FDI, financial development, democracy and political instability on economic growth in West Africa using a panel of 11 ECOWAS countries from 1996 to 2016 and employing the dynamic fixed effects technique. The results showed that FDI significantly spurred the sub-region's economic growth in the long run but had no significant link in the short run. In both the short and long run, financial development promoted growth while political instability significantly hindered the countries' growth, and democracy had insignificant effects.

Adegboye, Osabohien, Olokoyo, Matthew, and Adediran (2020) investigated the effects of institutional quality and FDI on economic development in a panel data of 30 sub-Saharan Africa (SSA) countries covering 2000 to 2018 adopting fixed and random effect estimations. The findings suggested that FDI influx, human development and quality of institutions significantly supported the economic development of SSA. However, FDI had insignificant positive effects on the economic development of West and South African sub-regions.

Ogundipe et al. (2020) examined whether infrastructural absorptive capacity stimulates FDI-growth nexus in ECOWAS utilizing a system GMM estimation of panel data from 1995 through 2017. The findings indicated that the growth of ECOWAS was less responsive to FDI influx, and the interaction of FDI and physical infrastructure hindered GDP growth of the sub-region.

Fofana et al. (2018) examined the dynamic relationship between Chinese FDI, agricultural sector and 
economic growth in West African from 2003 to 2015, applying panel Granger causality and pool mean group techniques. Findings showed a cointegration between China FDI, economic growth, domestic investment and land used for agriculture. Results also showed no causation between China FDI and economic growth. However, the authors concluded that Chinese FDI, domestic investment and the agricultural sector enhanced the economic growth of West Africa.

Ozekhome (2017) explored the effect of foreign aid and foreign direct investment on economic growth and whether the aid-growth link exhibits diminishing returns in 15 countries of ECOWAS using a panel dataset from 2005 through 2015 and employing the generalized method of moments (GMM) econometric technique. Findings indicated that foreign direct investment, trade openness, real gross domestic capital formation, human capital, and lagged real GDP significantly influenced economic growth in ECOWAS.

Ozekhome (2016) also examined trade openness and investment impacts on economic growth in the ECOWAS sub-region utilizing a dynamic panel dataset covering 2000 to 2013. The estimated GMM results showed that foreign direct investment, trade openness, real gross domestic capital formation, human capital and lagged real GDP are determinants of economic growth in ECOWAS due to their significant positive effects.

Tomi (2015) investigated the nexus between foreign direct investment and economic growth in West Africa Economic and Monetary Union WAEMU countries using time series data from 1970 to 2012. Results of the Toda-Yamamoto Granger causality and unrestricted error correction suggested three important findings:

1. Evidence exists of a strong long-run relationship between GDP per capita and the ratio of FDI inflows.

2. A bi-directional causality holds between the two variables.

3. There is a significant positive effect of FDI on Total Factor Productivity in the long run, conditional on a low level of depreciation of capital stock.

Azam and Hassan (2013) examined the impact of corruption, FDI and workers' remittances on economic growth in a set of five South and South-East Asian countries from 1985 to 2011 using a panel dataset in the fixed and random effects models; the study obtained evidence of the positive and statistically significant effect of foreign direct investment and remittances on economic growth.

Alege and Ogundipe (2013), in a system GMM panel estimation framework, explored the relationship between FDI and economic growth in ECOWAS using a dataset from 1970 through 2011 and interacting human capital and institutions indicators in explaining the variability of FDI. The findings were contrary to earlier studies, as the contribution of FDI was insignificant and negatively impacted growth in ECOWAS despite the controlling for the role of human capital and quality of institutions in the model.

Adamu, Ighodaro and Iyoha (2012) analyzed the effect of trade openness and FDI on countries of the West African Monetary Zone (WAMZ) employing the instrumental variable two-stage least squares (2SLS) estimation framework. The result suggested that trade openness, domestic investment, FDI, human capital development, and lag of economic growth are the vital drivers of economic growth in the WAMZ region as they all have a positive relationship with the latter.

Behname (2012) disclosed the linkage between FDI and economic growth in a study of Southern Asia from 1977 through 2009, adopting the random effect model. Results showed that FDI had a positive and significant effect on economic growth in the region. Economic infrastructure, capital formation and human capital development also positively impact the economic growth of the region.

Tiwari (2011) investigated the impact of foreign aid, FDI, and economic freedom for 28 selected Asian countries in panel data from 1998 through 2007 using the GMM estimation technique. The results indicated that fiscal freedom, financial freedom, domestic capital stock, freedom from corruption, FDI inflow, life expectancy and foreign aid were significant factors that positively impact economic growth.

Pradhan (2011) analyzed the role of FDI on the trade-led growth hypothesis in three countries (Australia, Canada and Israel) from 1965 to 2009 based on panel cointegration and causality tests. The results indicated a long-run relationship between FDI and economic growth after allowing for a heterogeneous country effect. The causality test confirms the long-run and short-run bi-directional causality between openness and economic growth. It also ensures a unidirectional causality from growth to FDI but not vice versa.

Ndambendia and Njoupouognigni (2010) also explored the long-run nexus between foreign aid, FDI and economic growth in 36 Sub-Saharan Africa (SSA) countries from 1980 through 2007, adopting the dynamic panel mean group (MG), pooled mean group (PMG), and dynamic fixed effect (DFE) estimation techniques. The results confirmed strong evidence of foreign aid and FDI's positive impact on economic growth in SSA.

Varamini and Kalash (2010) investigated the nexus between FDI and economic growth of 10 emerging countries in Europe before joining the European Union, using a dataset spanning 1980 to 2008 in a Granger causality econometric estimation. The result showed unidirectional causation from FDI to economic growth; and bidirectional causation between openness and FDI.

Malik (2010) analyzed the impact of foreign aid and FDI on the economic growth of the six poorest and highly aided dependent African countries (the Central African Republic, Malawi, Mali, Niger, Sierra Leone and Togo) employing panel cointegration estimation. The findings revealed a cointegrating relationship between real 
GDP per-capita, aid as a percentage of GDP, investment as a percentage of GDP and trade openness.

Lamine and Yang (2010) assessed the effect of FDI on the Guinea Republic's economic growth using Granger causality estimation on data series from 1985 to 2008. The estimated result showed that the country's FDI level is still low to enhance its economic growth. They also found that the level of gross domestic product and employment promoted FDI in the country. Further findings from the study showed that school enrolment had a direct positive impact on gross domestic product and an indirect positive effect on FDI in the Guinea Republic.

\section{Human Capital and Economic Performance}

Intisar, Yaseen, Kousar, Usman, and Makhdum (2020) assessed the impact of trade openness and human capital on economic growth in 19 Asian countries from 1985 to 2017 utilizing fully modified ordinary least squares (FMOLS) and dynamic ordinary least squares (DOLS) estimation approaches. The findings indicated that human capital and trade openness promoted economic growth significantly in Asia and Southern and Western Asian sub-regions. Moreover, FDI significantly spurred economic growth in Southern Asia but significantly stifled economic growth in Western Asia.

Anowor, Ichoku, and Onodugo (2020) examined the nexus between healthcare financing and economic performance of 15 countries in the ECOWAS sub-region employing panel autoregressive distributive lag (PARDL) estimation of data spanning 1985 to 2017. The authors found that private and public healthcare expenditures contributed significantly to the economic performance of ECOWAS.

Ogunbadejo and Kanwanye (2020) explored the impact of human capital on Nigeria's economic growth from 1970 through 2017 using two-stage least squares (2SLS) estimation approach. The findings showed that human capital measured by life expectancy and tertiary school enrollment, and physical capital, significantly promoted Nigeria's economic growth.

Musibau, Agboola, and Kafilah (2019) explored the relationship between foreign capital inflows, human capital development and economic growth in ECOWAS countries from 1980 to 2017 using the PMG estimation technique. Findings indicated that FDI, human capital and domestic investment spurred the growth of ECOWAS, though not significantly. In contrast, foreign capital influx and human development index greatly impacted the growth of the sub-region.

Fadila and Olure-Bank (2019) investigated the random impact of human capital development on the economic growth of ECOWAS countries from 1980 to 2016 using Pedroni residual cointegration approach. The results suggested that a long-run relationship exists among the variables. Also, expenditure on education, spending on health and school enrolment had a positive and statistically significant impact on the economic growth of the ECOWAS countries.

Olure-Bank and Fadila (2018) assessed human capital's effect on Nigeria's economic growth from 1986 to 2016 using a multiple regression framework. The results showed that capital health expenditure had a positive and significant effect on economic growth. In contrast, capital expenditure on education had a significant negative effect on economic growth in the country.

Ejemeyovwi, Osabuohien and Osabohien (2018) assessed linkage between information and telecommunication technology (ICT) investment and human capital development on economic transformation in ECOWAS from 2004 to 2015 using GMM estimation technique. The result indicated that ICT investment was not statistically related to human development. The authors claimed that investment in ICT and human development could transform the economy of ECOWAS.

Obialor (2017) examined the impact of public human capital investment on Nigeria's economic growth, South Africa and Ghana from 1980 to 2013, adopting vector error correction methodology (VECM). Findings revealed that government investment in health and government investment in education significantly impacted Nigeria's economic growth. In contrast, the literacy rate had an insignificant positive influence on economic growth in the three countries.

Adeyemi and Ogunsola (2016) explored the link between human capital indices and Nigeria's economic growth from 1980 to 2013 employing auto-regressive distributed lag (ARDL) estimation. The study found a positive long-run relationship among secondary school enrolment, public expenditure on education, life expectancy, gross capital formation and economic growth. However, the relative impacts of the explanatory variables were insignificant on economic growth.

Jameel and Naeem (2016) analyzed the nexus between human capital and economic growth using a panel of selected eleven developing countries from 1992 through 2014 in a fixed effect estimation. The result indicated a long-run link between the gross domestic product and human capital among the nations. That human capital has a positive impact on the economic growth of the countries.

Hamif and Arshed (2016) also investigated the effect of human capital in the form of education on the economic growth of southern African countries from 1960 to 2013 using ordinary least squares (OLS) and the fixed effect (FE) estimation methods. Results showed that education had a positive effect on the economic 
growth of the countries.

Boachie (2015) also employed the ARDL bounds test approach of cointegration to examine the relationship between human capital and Ghana's economic growth from 1982 to 2012. The result showed that health significantly drives economic growth in the country in both the long and short-run periods.

Lawanson (2015) examined if human capital does matter in the West African region's economic growth experience using data from 1980 to 2013 in a Differenced GMM estimation technique. The result showed that the estimated coefficients of all education and health variables positively and significantly impacted the region's economic growth.

Mat, Mansur and Mahmud (2015) examined the impact of human capital investment on education, health and migration on the economic development of Sahah in Malaysia from 1980 to 2010, employing the OLS technique. Results suggested that a better literacy rate, life expectancy at birth, required number of immigrants significantly promoted GDP per capita.

Owusu-Nantwi (2015) examined the nexus between human capital and economic growth in Ghana from 1970 to 2012 using the VECM technique. The findings showed that education expenditure, gross fixed capital formation, and labour force participation significantly impacted real GDP.

Mekdad, Dahmani and Louaj (2014) employed the OLS, Johansen cointegration and Granger causality techniques to investigate the relationship between human capital and Algeria's economic growth from 1974 to 2012. The findings supported the hypothesis that public education expenditure had a significant positive impact on Algeria's economic growth in the period.

Zivengwa, Hazvina, Ndedzu and Mavesere (2013) explored the causal relationship between economic growth and education in Zimbabwe from 1980 through 2008 using Granger causality and vector auto-regressive (VAR) techniques. The results suggested a unidirectional causality from education to economic growth and further confirmed a transmission mechanism from education to economic growth through investment in physical capital.

Khembo and Tehereni (2013) examined the relationship between human capital formation and economic development in the South African Development Community (SADC) from 1990 to 2005. The pooled OLS result indicated that education was positively related to the economic growth of the countries.

Hammani (2013) assessed the relationship between human capital development and economic growth in developed countries from 1975 through 2011, employing Granger causality and VAR methods. The results showed a long-run relationship between health care and economic growth; and that health expenditures positively influenced economic growth in developed countries.

Bakare and Sanmi (2011) inquired into the relationship between health care expenditure and economic growth in Nigeria from 1980 to 2010 using multiple regression OLS estimation. The results indicated that health care expenditure had a positive and statistically significant impact on the country's economic growth.

No consensus was reached on the FDI-economic growth nexus from reviewing the relevant strands of literature, whether at the country-specific or cross-country levels. None of the studies considered the influence of human capital in the FDI-growth nexus in ECOWAS. This paper, therefore, contributes to filling this gap.

\section{Methodology \\ Theoretical Framework}

This study is hinged on the endogenous growth model which explains that balanced growth is positively influenced by knowledge spillover, human capital (in the form of health and education), research and development, through their influence on the technical progress. Technological progress in this model is therefore endogenised and can be explained by some factors. Based on this model, Lucas (1988) put forward an endogenous growth model where human capital is a major driver of output growth. Lucas theorized that economic growth $\mathrm{Y}$ is a function of capital stock $(\mathrm{K})$, labour productivity $(\mathrm{A})$ and labour $(\mathrm{L})$. The related production function may be of the form

$\mathrm{Y}(\mathrm{t})=\mathrm{K}(\mathrm{t})^{\mathrm{a}}(\mathrm{A}(\mathrm{t}) \mathrm{L})^{1-\mathrm{a}}$

Where $A(t) L$ is effective labour with $a$ and $(1-a)$ as relative shares of $K$ and $A(t) L$, respectively in output. Now with the technical progress or labour productivity (A) being entirely explained by the stock of human capital, say $\mathrm{H}$, that is, human capital increases labour productivity

$\mathrm{A}=\mathrm{f}(\mathrm{H})$

Considering constant returns to scale to the produced inputs in both goods and research sectors, and let research and development $(\mathrm{R} \& \mathrm{D})$ uselabour and the existing stock of human capital, but not physical capital, whereas goods production uselabour, human and physical capital. The production function for labour productivity is given by:

$\dot{A}(t)=B a_{l} L A(t)$ .3

and since all physical capital is used to produce goods, goods production is

$Y(t)=K(t)^{a}\left[\left(1-a_{1}\right) L A(t)\right]^{1-a}$ 
Where $A(t)$ denotes a derivative of labour productivity with respect to time [that is, Á(t)is a shorthand for $\frac{d A(t)}{d t} ; B$ is a shift parameter [which accounts for all other factors affecting rate of change of labour productivity other than labour and labour productivity]; $\mathrm{a}_{1}$ and 1-a denote the fraction of labour used in labour productivity and goods production, respectively; and $\alpha$, represents the elasticity of output with respect to capital stock, while 'L, A, K and Y are labour force, effectiveness of labour, capital stock and output, respectively. Notice that time $(\mathrm{t})$ enters the 'model continuously in line with [the prescriptions of] the endogenous growth theory. Dividing Equation 4by LA yields

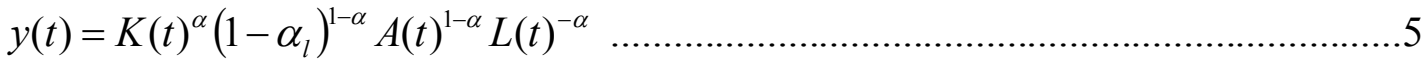

where y denotes output per man. On taking the log transformation and introducing human capital into the equation, we have

$\ln \gamma(t)=\alpha_{0}+(1-\alpha) \ln H(t)+\alpha \ln K$

Thus the Equations 6 is the fundamental equation adopted for this study. It simply shows that physical capital stock including direct foreign investment and human capital stock in the form of health and education, are an important determinants of economic performance.

\section{Model Specification}

Drawing from the theoretical framework above and following Adamuet al (2012), Alege and Ogundipe (2013), Ozekhome (2016, 2017), and Fadila and Olure-Bank (2019); the empirical model for the study is specified below.

$\Delta \ln R G D P_{t, t}=\alpha_{i}+\sum_{k=1}^{p} \alpha_{1 i k} \Delta \ln R G D P_{1 i, t-k}+\sum_{k=0}^{q} \alpha_{2 i k} \Delta \ln G F C F_{1 i, t-k}+\sum_{k=0}^{q} \alpha_{3 i k} \Delta \ln D F I_{1 i, t-k}+\sum_{k=0}^{q} \alpha_{4 i k} \Delta \ln L E X_{1 i, t-k}+\sum_{k=0}^{q} \alpha_{5 i k} \Delta \ln S C H_{1 i, t-k}$ $+\sum_{k=0}^{q} \alpha_{6 i k} \Delta \ln \left(D F F^{*} L E X\right)_{1 i, t-k}+\sum_{k=0}^{q} \alpha_{\eta_{i k}} \Delta \ln \left(D F F^{*} S C H\right)_{1 i, t-k}+\beta_{1 i, t} \ln R G D P_{t, t-1}+\beta_{2 i, t} \ln G F C F_{i, t-1}+\beta_{3 i, t} \ln D F I_{i, t-1}$ $+\beta_{4 i, t} \ln L E X_{i, t-1}+\beta_{5 i, t} \ln S C H_{i, t-1}+\beta_{6 i, t} \ln D F F^{*} L E X_{i, t-1}+\beta_{7 i, t} \ln D F F^{*} S C H_{i, t-1}+\varepsilon_{i, t} \ldots \ldots \ldots \ldots \ldots \ldots \ldots . .7$

Equation 7 is an unrestricted panel autoregressive distributed lag (PARDL) model where ln = natural logarithm, RGDP $=$ real GDP, GFCF = gross fixed capital formation, FDI $=$ direct foreign investment, LEX $=$ life expectancy at birth, $\mathrm{SCH}=$ total school enrolment, FDI*LEX = interaction of FDI and LEX, FDI*SCH = interaction of FDI and $\mathrm{SCH}$, the $\alpha \mathrm{s}$ and $\beta \mathrm{s}$ are the short run and long run parameters, respectively to be estimated; $\varepsilon_{i, t}$ is the error term related to country $\mathrm{i}$ at time $\mathrm{t}$ assumed to have zero mean and constant variance; while $\mathrm{p}$ and $\mathrm{q}$ are the order of lags in the model, and $\Delta=$ difference operator. Equation 7 is further expressed in its restricted version as

$$
\begin{aligned}
& \Delta \ln R G D P_{t, t}=\alpha_{i}+\sum_{k=1}^{p} \alpha_{1 i k} \Delta \ln R G D P_{1 i, t-k}+\sum_{k=0}^{q} \alpha_{2 i k} \Delta \ln G F C F_{1 i, t-k}+\sum_{k=0}^{q} \alpha_{3 i k} \Delta \ln D F I_{1 i, t-k}+\sum_{k=0}^{q} \alpha_{4 i k} \Delta \ln L E X_{1 i, t-k}+\sum_{k=0}^{q} \alpha_{5 i k} \Delta \ln S C H_{1 i, t-k}
\end{aligned}
$$

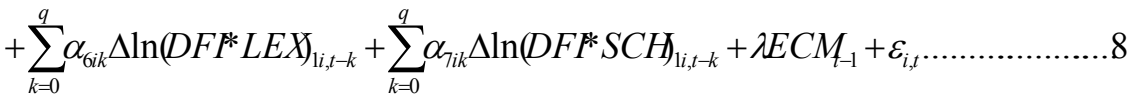

where $\mathrm{ECM}_{\mathrm{t}-1}$ is the error correction mechanism and $\lambda$ is the speed of adjustment of the model.

According to theoretical postulations, we expect all the explanatory variables to be positively related to the dependent variable except for foreign investment which can also be negatively correlated with the dependent variable. Foreign investment in an economy can have a promoting of hindering effect on economic growth of a country as such investment inflows either complement existing stock of capital to support economic growth or substitute same to adversely affect the economy of the country.

Domestic investment is also expected to positively influence economic growth. Empirical studies have confirmed that investments, be it domestic or foreign, increase the both level and growth of capital stock which spurs the growth of an economy. Also from the theoretical and empirical literature review undertaken by the study, human capital development is a vital factor that support the growth of an economy. Consequent on this, we expect the indicators of human capital development in the form of life expectancy and school enrolment to have a positive impact on the growth of an economy. The interaction effect of human capital development and direct foreign investment is also expected to be positive or negative.

\section{Estimation Procedure}

It is necessary to examine the stationarity properties of the variables in a panel data. A key assumption for a dynamic model estimator requires the first differences of all the variables to be uncorrelated with the individual effects. This assumption is guaranteed to be valid if the series have constant mean over time or are integrated of 
the first order. An integrated series needs to be differenced in order to achieve stationarity. Given that the countries in this study constitute a cross sectional dimension, and pooling data over a long time series, the issue of stationarity and cointegration became inevitable. The first step taken was to analyse the order of integration of the variables. To provide robustness and exploit the additional information in the cross sectional dimension of the data, the study employed two panel data unit root tests, namely Levin, Lin and Chu (LLC) (2002) and Im, Pesaran and Shin (IPS) (2003) each having the general form as

$$
\Delta y_{i t}=k_{i}+\alpha y_{t, t-1}+\beta_{i} t+\sum_{j=1}^{p} \varphi_{i t} \Delta y_{i, t-j}+\varepsilon_{i t}
$$

While the LLC (2002) considers a common unit root process of variables, the IPS (2003) considers individual unit root process of variables.

To check for the existence or otherwise of long run relationship between FDI and economic performance in ECOWAS, the Pedroni (1999) cointegration test, a residual based, was utilised. The Pedroni (1999) test assume trend for the cross sections and consider the null hypothesis of no cointegration in panel data. This allow multiple regressors for the cointegration vector to vary across different sections of the panel as well as heterogeneity in the error term. The Pedroni panel regression model has the following form

$y_{i t}=\alpha_{i}+\delta_{t}+\sum_{m=1}^{M} \beta_{m i} x_{m i, t}+u_{i t}$

Seven different cointegration statistics were used to capture the 'within' and 'between' effects in the panel. A major drawback of this procedure is the restrictive a priori assumption for a unique cointegrating vector. Thus, the Johansen-Fisher (2000)cointegration test which involves testing a system of equations was also used alongside the Pedroni approach, in this study.

A dynamic strategy was used to explore the long run link of FDI and economic growth with cross section heterogeneity. The heterogeneity arises as a result of country specific factors since such factors could play critical role over the time period. In this regard, Pesaran, Shin and Smith (2001) noted that both the mean group $(\mathrm{MG})$ and the pooled mean group (PMG) estimators are essential procedures for application on panel with large $\mathrm{N}$ or $\mathrm{T}$.

The PARDL model was estimated using the dynamic pooled mean group (PMG) estimation technique proposed by Pesaran et al (2001). The method is obtained from autoregressive distributed lag (ARDL) models for each unit consisting of long term average by using the coefficient of the long term (Tuluce\&Dogan, 2014).

\section{Data}

A panel data of all the variables were sourced from the World Bank's World Development Indicators (WDI) (2019). The variables were annual time series covering the period 1980 to 2018 across 15 ECOWAS countries. The period was chosen to allow for a long run analysis post-formation of ECOWAS.

Economic performance was measured by real gross domestic product (RGDP) in constant 2010 US dollars. The independent variables were measured as follows: domestic investment measured by gross fixed capital formation (GFCF); foreign investment measured by FDI as a percentage of GDP. Other independent variables capturing human capital development indicators were life expectancy at birth (LEX) and total school enrolment rate $(\mathrm{SCH})$ percentage of total population.

\section{Results and Discussion}

Table 1:Descriptive Statistics of Variables 1980-2018.

\begin{tabular}{c|c|c|c|c|cc}
\hline Variables & Mean & \multicolumn{1}{l|}{ Median } & Maximum & Minimum & Std. Dev. & Jarque-Bera \\
\hline RGDP & $2.37 \mathrm{E}+10$ & $4.58 \mathrm{E}+09$ & $4.64 \mathrm{E}+11$ & $3.31 \mathrm{E}+08$ & $6.71 \mathrm{E}+10$ & $12801.64 * * *$ \\
GFCF & $1.27 \mathrm{E}+11$ & $1.17 \mathrm{E}+09$ & $4.92 \mathrm{E}+12$ & $-3.7 \mathrm{E}+07$ & $4.69 \mathrm{E}+11$ & $52085.72 * * *$ \\
FDI & 2.102667 & 1.207065 & 32.30119 & -28.6243 & 3.524010 & $13415.34 * * *$ \\
LEX & 52.05678 & 52.44700 & 67.14600 & 35.70500 & 6.112740 & $9.236193^{* * *}$ \\
SCH & 14.62261 & 6.579370 & 60.41460 & 0.213220 & 15.93518 & $157.8555^{* * *}$ \\
& & & & & & \\
\hline
\end{tabular}

Note: $* * *$ denotes significance at $1 \%$ level.

Source: Researcher's compilation from Eviews version 9.0 output.

Table 1 shows the descriptive statistics of the variables considered in the study. Average annual real gross domestic product (RGDP) was $\$ 23.7$ billion $(S D=\$ 67.1$ billion), average value of GFCF was $\$ 12.7$ billion ( $S D$ 
$=\$ 46.9$ billion), average annual FDI inflows percent of GDP was 2.1 percent $(S D=3.52$ percent $)$, average annual total life expectancy at birth (LEX) was 52.1 years $(S D=6.11$ years), and average tertiary school enrolment percent of gross $(\mathrm{SCH})$ was 14.6 percent ( $\mathrm{SD}=15.94$ percent) The statistics suggest that RGDP had the highest variability in its values among the variables considered, while LEX had the least variability. Moreover, all the variables considered were not normally distributed, individually.

Table 2:Levin, Lin and Chu Common Unit Root Test

\begin{tabular}{c|c|c|c|c|c}
\hline & Levels & First Difference & \\
\cline { 2 - 6 } & Statistic & Probability & Statistic & Probability & Remarks \\
\hline RGDP & 5.12885 & 1.0000 & -6.41248 & 0.0000 & $\mathrm{I}(1)$ \\
GFCF & 3.70444 & 0.9999 & -6.46226 & 0.0000 & $\mathrm{I}(1)$ \\
FDI & -3.06317 & 0.0011 & Nil & nil & $\mathrm{I}(0)$ \\
LEX & -20.5097 & 0.0000 & nil & nil & $\mathrm{I}(0)$ \\
SCH & 0.22236 & 0.5880 & -7.00768 & 0.0000 & $\mathrm{I}(1)$ \\
\hline
\end{tabular}

Source: Researcher's compilation from Eviews version 9.0 output.

Table 2 presents the result of LLC (2002) common unit root process both at levels and first difference. At levels, FDIand LEX are stationary, judging from the significance of these variables at the 1 percent level as revealed by the probability values of the LLC statistics. On the other hand, RGDP, GFCF and SCH became stationary after first difference. This can be observed from the significance of the LLC statistical values at the 1 percent level, suggesting a rejection of a unit root after differencing these variables once. Thus, the panel dataset contains variables that are integrated of order zero [I(0): FDI, and LEX] and integrated of order one [I(1): RGDP, GFCF and $\mathrm{SCH}]$.

Table 3:Im, Pesaran and Shin Individual Unit Root Testest

\begin{tabular}{c|c|c|c|c|c}
\hline & \multicolumn{2}{|c|}{ Levels } & First Difference & \multirow{2}{*}{ Remarks } \\
\cline { 2 - 5 } & Statistic & Probability & Statistic & Probability & I(1) \\
\hline RGDP & 9.63127 & 1.0000 & -7.75072 & 0.0000 & $\mathrm{I}(1)$ \\
GFCF & 5.86041 & 1.0000 & -9.48155 & 0.0000 & $\mathrm{I}(0)$ \\
FDI & -4.21171 & 0.0000 & nil & nil & $\mathrm{I}(0)$ \\
LEX & -15.8291 & 0.0000 & nil & 0.0000 & $\mathrm{I}(1)$ \\
SCH & 2.51691 & 0.9941 & -8.82737 & & \\
\hline
\end{tabular}

Source: Researcher's compilation from Eviews version 9.0 output.

Table 3 provides the outcome of the (IPS) (2003) individual unit root tests at levels and first difference. The IPS statistics of FDI and LEX were significant at the 1 percent level, indicating that a null hypothesis of unit root is rejected for these variables. Thus, FDI and LEX are stationary at levels. After differencing other variables (RGDP, GFCF and SCH) once, the IPS statistics were significant at the 1 percent level suggesting that the variables have no unit roots after first differencing. Therefore, the IPS approach also concludes that the panel dataset contains variables that are integrated of order zero [I(0) i.e. FDI and LEX] and integrated of order one [I(1) i.e. RGDP, GFCF and SCH].

Table 4: Pedroni Residual Based Test

\begin{tabular}{l|l|l}
\hline \multicolumn{1}{c|}{ Test } & $\underline{\text { Statistic }}$ & $\underline{\text { Prob. }}$ \\
\hline Panel v-Statistic & 3.626834 & 0.0001 \\
Panel rho-Statistic & 0.406552 & 0.6578 \\
Panel PP-Statistic & -4.75591 & 0.0000 \\
Panel ADF-Statistic & -4.44174 & 0.0000 \\
\hline
\end{tabular}

Source: Researcher's compilation from Eviews version 9.0 output.

The result of Pedroni (1999) residual based cointegration test is displayed on Table 4. From the table, three out of the four tests had significant statistical values at the 1 percent level. These include the panel v-statistic, panel Philip-Perron statistic and the panel Augmented Dickey-Fuller statistic. Only the panel rho-statistic value was not significant. The results therefore imply that a hypothesis of no cointegration among the variables is rejected. Hence, a long run relationship exists among the variables. 
Table 5: Johansen-Fisher Cointegration Test

\begin{tabular}{|c|c|c|c|c}
\hline $\begin{array}{c}\text { Hypothesized No. } \\
\text { of CE(s) }\end{array}$ & $\begin{array}{c}\text { Fisher Stat. (Trace } \\
\text { test) }\end{array}$ & Prob. & $\begin{array}{c}\text { Fisher Stat. (Max- } \\
\text { eigen test) }\end{array}$ & Prob. \\
\hline None & 397.3 & 0.0000 & 259.5 & 0.0000 \\
At most 1 & 217.0 & 0.0000 & 124.4 & 0.0000 \\
At most 2 & 120.1 & 0.0000 & 72.50 & 0.0000 \\
At most 3 & 74.72 & 0.0000 & 53.48 & 0.0012 \\
At most 4 & 67.53 & 0.0000 & 67.53 & 0.0000 \\
\hline
\end{tabular}

Source: Researcher's compilation from Eviews version 9.0 output.

In Table 5 is the result of the Johansen-Fisher cointegration test. The outcomes of the Trace test and the Maximum-Eigen test statistics revealed that their statistical values were all significant at the one percent level. The implication is that a null hypothesis of no cointegration is rejected in favour of its alternative, and there exists at most four cointegrating equations including the one specified for this study.

The pooled mean group (PMG) estimation included observations of each variables which cuts across 13 ECOWAS countries, excluding Cape Verde and Liberia due to data unavailability, from 1980 to 2017. The optimal model selected for the analyses is the PARDL $(1,1,1,1,1,1,1)$ process and its short run and long run estimates are discussed below.

Table 6: Short run estimates of PARDL model.

\begin{tabular}{c|c|c|c|c}
\hline Variable & Coefficient & Standard Error & t-Statistic & Prob. $^{*}$ \\
\hline C & 0.037159 & 0.029201 & 1.272527 & 0.204 \\
D(LNGFCF) & 0.053576 & 0.012634 & 4.240735 & 0.0000 \\
D(LNFDI) & 0.393138 & 0.422591 & 0.930304 & 0.3528 \\
D(LNLEX) & 1.640156 & 1.241362 & 1.321255 & 0.1872 \\
D(LNSCH) & 0.001116 & 0.031224 & 0.035749 & 0.9715 \\
D(LNFDI*LNLEX) & -0.12303 & 0.124903 & -0.98497 & 0.3253 \\
D(LNFDI*LNSCH) & 0.019209 & 0.019279 & 0.996385 & 0.3197 \\
ECM(-1) & -0.02972 & 0.016161 & -1.83863 & 0.0667 \\
\hline
\end{tabular}

Source: Researcher's compilation from Eviews version 9.0 output.

The estimated short run model (Table 6) was quite good as the error correction mechanism or the cointegrating equation $[\mathrm{ECM}(-1)]$ has a coefficient that is negative and significant at the 10 percent level. Its value of -0.0297 indicated that about 3 percent of the deviations of the model from its long run value, in previous period, are corrected in the current period. This speed of adjustment of the model is therefore very slow.

All the estimated coefficients met the a priori expectations in line with economic theory. However, these coefficients were not significant even at the 10 percent level, except that of GFCF (significant at 1 percent). On average, a 10 percent rise in GFCF, FDI, LEX and SCH increase economic performance of ECOWAS in the short run by $0.05,0.39,1.64$ and 0.001 percent, respectively.

Moreover, coefficient of the interaction term FDI*SCH was positive while FDI*LEX was negative implying that a 10 percent rise in FDI*SCH and FDI*LEX will lead to 0.2 percent increase and 0.12 decrease in economic performance, respectively, in ECOWAS. Thus, FDI has an indirect positive and negative impacts on economic performance of ECOWAS, through SCH and LEX, respectively.

Table 7:Long run estimates of PARDL model.

\begin{tabular}{c|c|c|c|c}
\hline Variable & Coefficient & Standard Error & t-Statistic & Prob. $^{*}$ \\
\hline LNGFCF & 0.318636 & 0.070283 & 4.533613 & 0.0000 \\
LNFDI & 8.323477 & 3.112469 & 2.674236 & 0.0078 \\
LNLEX & 3.909724 & 0.881247 & 4.436579 & 0.0000 \\
LNSCH & 0.223708 & 0.073039 & 3.062869 & 0.0023 \\
LNFDI*LNLEX & -2.12436 & 0.794955 & -2.6723 & 0.0079 \\
LNFDI*LNSCH & 0.045431 & 0.035653 & 1.274256 & 0.2033 \\
\hline
\end{tabular}

Source: Researcher's compilation from Eviews version 9.0 output.

The long-run result of the PARDL model is presented in Table 7. The result shows that all the estimated coefficients had the correct signs as posited in economic theories and significant (at 1 percent) except FDI*SCH. On average, a 10 percent rise in GFCF, FDI, LEX, and SCH will increase the economic performance of ECOWAS in the long run by $0.32,8.32,3.91$ and 0.22 percent, respectively.

In addition, a 10 percent rise in FDI*SCH and FDI*LEX, on average, resulted in 0.05 and 2.12 percent increase and decrease, respectively, in the economic performance of ECOWAS. Therefore, FDI has an indirect positive impact through SCH on the economic performance of ECOWAS, whereas it (FDI) has a significant 
effect, through LEX, on the economic performance of the sub-region.

\section{Conclusion}

The estimated results showed that FDI had a positive effect on the economic performance of the ECOWAS subregion in the short run, and the effect became significant in the long run. Findings also revealed that human capital hindered the economic performance effect of FDI in ECOWAS in the short run and long-run through life expectancy, but with a fragile positive impact through education in both time horizons.

Therefore, it is pertinent for ECOWAS as a body and its member nations to establish and entrench policies that would favour or encourage the inflow of FDI into the sub-region as a whole and their countries in particular. Policies like tax holidays to attract new and more FDI in the sub-region can be encouraged. The sub-region governments and relevant bodies should provide other investment-friendly frameworks like having welldeveloped financial and stock markets to attract inflows of such foreign investments. More so, governments in the sub-region can leverage the long-run benefits of FDI in the sub-region for long term development plans.

The sub-region governments need to improve on their human capital formation policies to enable them to harness the full benefits of FDI inflows into ECOWAS. The sub-region governments should scale-up annual funds allocated to the health and education sub-sectors to improve on the available human capital resources. Provisions should be made to train and re-train available human capital base in the sub-region to understand and probably absorb technology transfer related to the inflow of FDI into ECOWAS. The government of ECOWAS should put in place frameworks to promote the acquisition of tertiary education and other higher specialized skills to reap the full benefits of FDI into the sub-region.

This paper concludes that foreign direct investment, domestic investment and human capital (mainly health) are vital determinants of the economic performance of ECOWAS. Human capital development in ECOWAS does not support the positive impact of foreign direct investment in the sub-region.

\section{Contributions to Knowledge}

First, the study examined the role of human capital development in the relationship between foreign direct investment and economic growth in ECOWAS. Previous studies carried out by other authors did not consider this in their work, especially regarding the ECOWAS sub-region case. Foreign direct investment has both direct and indirect impacts on the economy, as posited by theory. This, therefore, necessitated an evaluation of this theoretical assertion as it relates to the direct foreign investment and economic growth nexus in ECOWAS with interest in how the former impacts the latter through human capital development in the sub-region.

\section{References}

Adamu, P. A., Ighodaro, C.A.,\&Iyoha, M.A. (2012). Trade, foreign direct investment and economic growth: Evidence from the countries of the West African Monetary Zone. The West African Economic Review, 1(2), 10-31.

Adegboye, F. B., Osabohien, R.,Olokoyo, F. O., Matthew, O., \&Adediran, O. (2020). Institutional quality, foreign direct investment, and economic development in sub-Saharan Africa. Humanities and Social Sciences Communications, 7(38), 1-9. https://doi.org/10.1057/s41599-020-0529-x

Adeyemi, P.A., \&Ogunsola, A.I. (2016). The impact of human capital development on economic growth in Nigeria: ARDL approach. JOSP Journal of Humanities and Social Sciences, 21(3), 01-07.

Alege, P.O.,\&Ogundipe, A.A. (2013). Foreign direct investment and economic growth in ECOWAS: A system GMM approach. Covenant Journal of Business and Social Sciences, 5(1), 1-20. Retrieved from: https://www.researchgate.net/publication/275017498_Foreign_Direct_Investment_and_Economic_Growth in_ECOWAS_A_System-GMM_Approach

Anowor, O. F.,Ichoku, H. E.,\&Onodugo, V. A. (2020). Nexus between healthcare financing and output per capita: Analysis of countries in ECOWAS sub-region. Cogent Economics and Finance, 8(1). DOI: $10.1080 / 23322039.2020 .1832729$

Azam, M., \& Hassan, S. (2013). Corruption, workers' remittances, foreign direct investment and economic growth in five South and South East Asian countries: A panel data approach. Middle-East Journal of Scientific Research, 15 (2), 184-190.

Bakare, A.S., \&Sanmi, E.D. (2011). The effect of health on economic growth: Theory and evidence. NISER Working Paper Series, No 8587, available on http://www.niser.org/papers/w8587.

Behname, M. (2012). Foreign direct investment and economic growth: Evidence from Southern Asia. Atlantic Review of Economics, 2: 1-14.

Boachie, M.K. (2015). Effects of health on economic growth in Ghana: An application of ARDL bounds test to cointegration. MPRA Paper No. 67201, posted October 21, 2016.

Ejemeyovwi, J.O., Osabuohien, E.S. \&Osabohien, R. (2018). ICT investments, human capital development and institutions in ECOWAS.International Journal of Economics and BusinessResearch, 15(4), 463-474. 
Fadila, K. U., \&Olure-Bank, A. (2019). Effect of human capital development on economic growth of ECOWAS member states. Advances in Sciences and Humanities 5(1), 27-42.

Fofana, K. H., Xia, E., \&Traore, M. B. (2018). Dynamic relationship between Chinese FDI, agricultural sector and economic growth in West African: An application of the pool mean group modelJournal of Physics Conference Series, 1060,doi:10.1088/1742-6596/1060/1/012066

Hamif, N., \&Arshed, N. (2016). Relationship between school education and economic growth: SAARC countries. International Journal of Economic and Finance, 6(1), 294-300.

Hammani, J. (2013). Public health expenditure and economic growth in developed countries. International Journal of Economic Studies, 3(1), 23-34.

Im, K.S., Pesaran, M.H., \& Shin, Y. (2003). Testing for unit root in heterogeneous panels. Journal of Econometrics, 115, 53-74.

Intisar, R. I.,Yaseen, M. R.,Kousar, R., Usman, M. \&Makhdum, M. S. (2020). Impact of trade openness and human capital on economic growth: A comparative investigation of Asian countries. Sustainability, 12, 2930.doi:10.3390/su12072930

Jameel, S., \&Naeem, M.Z. (2016). Impact of human capital on economic growth: A panel study. Bulletin of Business and Economics, 5 (4), 231-238.

Khembo, F., \&Tehereni, B.H.M. (2013). The impact of human capital on economic growth in the SADC region. Developing Country Studies, 3(4), 144-152.

Lamine, K.M., \&Yang, D. (2010). Foreign direct investment effect on economic growth: Evidence from Guinea Republic in West Africa. International Journal of Financial Research, 1 (1), 49-54.

Lawanson, A.O. (2015). Economic growth experience of West African region: Does human capital matter?International Journal of Business and Social Science 6 (12), 127-137.

Levin, A., Lin, C.F., \& Chu, C. (2002). Unit root tests in panel data: Asymptotic and finite sample properties. Journal of Econometrics, 108, 1 -24.

Lucas S.R. (1988). The mechanics of economic development. Journal of Monetary Economics22(1), 30-42.

Malik, J. (2010). Foreign aid and economic growth: Cointegration analysis of the six poorest African countries. Economic Analysis and Policy, 38(2).

Mat, N.A., Mansur, K., \& Mahmud, R. (2015). The relationship between human capital investment and economic development in Sahah, Malaysia. Journal of Business and Economics, 2(1), 83-107.

Mekdad, Y., Dahmani, A., \&Louaj, M. (2014). Public spending on education and economic growth in Algeria: Causality test. International Journal of Business and Management, 2(3), 55-67.

Musibau, H. O., Agboola, Y. H., \&Kafilah, L. G. (2019) Endogenous specification of foreign capital inflows, human capital development and economic growth: A study of pool mean group.International Journal of Social Economic..https://doi.org/10.1108/IJSE-04-2018-0168

Ndambendia, H.,\&Njoupouognigni, M. (2010). Foreign aid, foreign direct investment and economic growth in Sub-Saharan Africa: Evidence from pooled mean group estimator (PMG). International Journal of Economics and Finance, 2(3).

Obialor, M.C. (2017). The effect of government human investment on economic growth of Sub-Sahara African countries: Evidence from Nigeria, South Africa and Ghana 1980-2013. International Journal of Asian Social Science, 7 (4), 328-339.

Ogunbadejo, H. K., \&Kanwanye, H. T. (2020). Human capital and economic growth in Nigeria: Does lifeexpectancy and schooling matter? Journal of Economics and Sustainable Development, 11(16), 81-91. DOI: $10.7176 / \mathrm{JESD} / 11-16-10$

Ogundipe, A. A., Oye, Q. E., Ogundipe, O. M.\&Osabohien, R. (2020). Does infrastructural absorptive capacity stimulate FDI-growth nexus in ECOWAS? Cogent Economics and Finance, 8(1), 1-19. DOI:10.1080/23322039.2020.1751487

Olure-Bank, A. M. \& Usman, F.K. ((2018). Nexus of human capital development on economic development in Nigeria 1981-2016. Available online at https://www.researchgate.net/

Owusu-Nantwi, V. (2015). Education expenditures and economic growth: Evidence from Ghana. Journal of Economics and Sustainable Development, 6(16), 69.

Ozekhome, H.O. (2016). Trade openness, investment and economic growth: Evidence from ECOWAS countries. West African Financial and Economic Review (WAFER), 16(1).

Ozekhome, H.O. (2017). Foreign aid, foreign direct investment and economic growth in ECOWAS countries: Are there diminishing returns in the aid-growth nexus? West African Journal of Monetary and Economic Integration, 17(1), 61-84.

Pedroni, P. (1999). Critical values for cointegration tests in heterogeneous models with multiple regressors. Oxford Bulletin of Economics and Statistics, 61, 653-670.

Pesaran, M. H., Shin, Y., \& Smith, R. J. (2001). Bounds testing approaches to the analysis of level of relationship. Journal of Applied Economics, 16, 289-326. 
Pradhan, J. P. (2011). Emerging multinationals: A comparison of Chinese and Indian outward foreign direct investment. International journal of Institutions and Economies, 3(1), 113-148.

Tiwari, A. K. (2011). Foreign aid, FDI, economic freedom and economic growth in Asian Countries. Global Economic Journal, 11(3), 32-46.

Tomi, S. (2015). Foreign direct investment, economic growth and structural transformation: The case of West African Economies and Monetary Union (WAEMU) countries. MPRA Paper 62230.

Tülüce, N.S.,\&Doğan, İ. (2014), The impact of foreign direct investments on SMEs' development.Procedia Social and Behavioral Sciences, 150, 107-115.

Varamini, H.,\&Kalash, S. (2010). Foreign direct investment inflows, economic growth, and trade balance: The experience of new members of the European Union. Journal of East- West Business, 16(1), 4-23.

World Development Indicators (2019). World Bank database.

Yusuf, H. A., Shittu, W. O., Akanbi, S. B., Umar, H. M., \&Abdulrahman, I. A. (2020). The role of foreign direct investment, financial development, democracy and political instability on economic growth in West Africa. International Trade, Politics and Development,4(1), 27-46. DOI 10.1108/ITPD-01-2020-0002

Zivengwa, T., Hazvina, F., Ndedzu, D., \&Mavesere, I.M. (2013). Investigating the causal relationship between education and economic growth in Zimbabwe. Asian Journal of Humanities and Social Studies, 1(5), 399411. 